DOI: https://doi.org/10.32839/2304-5809/2019-3-67-18

UDC 37.013

Illiakhova Maryna

University of Educational Management

\title{
CREATIVE ACTIVITY OF PERSONALITY IN THE CONTEXT OF FORMATION OF EDUCATIONAL MODELS
}

Summary. The display of creative activity of the personality in the development of culture have been theoretically and methodologically analyzed and its value in the formation of educational models has been established. The characteristic features of contemplative, operational, innovative and creative educational models are determined. The isomorphism of education and culture, which presupposes correspondence of educational model signs to characteristics of current culture is proved. It is established that the creative model of education should reflect the fundamental features of the information society and the co-evolutionary type of relations in the "man-world" system. This model should become a coherent educational environment that not only satisfies the society's demand for innovation, but also provides self-determination of educational activity, forms the person's ability to control the transfer of the dominant components of their own creative activity and realize the possibilities of a professional and life-personal system.

Keywords: innovation, creative model of education, creative activity, determination, self-development.

Ілляхова Марина

ДВНЗ «Університет менеджменту освіти» НАПН України

\section{КРЕАТИВНА АКТИВНІСТЬ ОСОБИСТОСТІ У КОНТЕКСТІ ФОРМУВАННЯ ОСВІТНІХ МОДЕЛЕЙ}

\begin{abstract}
Анотація. Зміст статті містить теоретико-методологічний аналіз сутності і значення креативної активності особистості у формуванні освітніх моделей і розвитку культури. Визначено характерні ознаки споглядальної, операційної, інноваційної і креативної освітніх моделей, що дозволяе розглядати розвиток освітніх моделей як динамічний процес актуалізації, виникнення, утвердження, кризи, зміни, компонентів креативної активності людини. Соціокультурний розвиток можливий в умовах коеволюційної креативності, яка передбачає паритет людини і світобудови, оріентуе креативну активність особистості на захист співіснування у світі. Дослідження соціокультурного розвитку і типів креативної активності особистості визначених в освітніх моделях, дозволяе зафіксувати, з одного боку ізоморфність освіти - репрезентацію в освітніх моделях ознак активності особистості, і з іншого - кваліфікувати освіту як механізм культурогенезу, оскільки саме в його межах формуеться суб'єкт культури, здатний реалізовувати культурні програми майбутнього. Встановлено, що креативна модель освіти має відображувати фундаментальні ознаки інформаційного суспільства і коеволюційний тип відносин у системі «людина-світ». У разі невідповідності цих ознак, в освіті, як підсистемі культури, настає криза перехідного періоду. Вихід з ціеї ситуації можливий у двох варіантах: або підсистема адаптуеться до класифікаційних ознак нової культури і тоді відбувається подальша культурна еволюція, або підсистема повертаеться до традиційних форм, що призводить до культурної стагнації. Креативна освіти модель має стати когерентним освітнім середовищем, що не тільки задовольняе запит суспільства на інноваційність, але і забезпечуе самодетермінацію освітньої діяльності, формуе у особистості навички контролювати трансфер домінант власної креативної активності і усвідомлювати можливості професійної та життево-особистісної системи.
\end{abstract}

Ключові слова: інновація, креативна модель освіти, креативна активність, самодетермінація, саморозвиток.

Tntroduction. Modern scientific knowledge,

new trends in the development of the informational world, the accelerated development of innovations are gradually destroying the established stereotypes of modernism epoch. Modernity engages us into a new normativity, organization of intellectual activity and leads beyond the limits of standardization, synchronization, and linearity. The modern world demands from us initiative, creativity, innovation, each time actualizing the conflict between the dogma of our thinking and the ever-increasing wave of new challenges. But still prioritized is reproductive, classical model of education that satisfies the third psyche level of personality (A. Leontiev), but leaves beyond activation the level of creative activity. Also, in modern processes of diversification, technification of cognitive activity, accelerates the rate of increasing of the amount of knowledge and the number of disciplines. Inhomogeneous, unpredictable sociality re- quires from a person each time to expand strategies of his own behavior, to create alternative activity practices, while the architectonics of the teaching process is mainly based on the binary classical logic "or-or», which is closed for the possibility of creating variational nonlinear praxeological scenarios. Accordingly, a modern, creative model of education that would correspond to the methodological guidelines of the nonlinear paradigm, the principles of postmodern society and market principles of an innovative type of economy should be formed.

Analysis of recent research and publications. Understanding of the dynamics of educational systems and the formation of models of education in modern pedagogy and education is solved from the standpoint of different approaches. In particular, the formation of a humanistic approach in education is reflected in the studies of V. Andrushchenka, G. Balla, B. Bim-Bada, G. Voleta, I. Zyazyun, V. Kremenya, V. Lugovogo, Z. Patterson and 
others. From the point of view of the culturological approach the problem of education was solved by V. Astakhov, O. Gazman, O. Ivanov, N. Krylov and others. Hermeneutic aspects of education were in the spotlight of A. Zakirova, V. Zinchenka, Y. Senko, I. Sulima and others. In the framework of the axiological approach, the problems of education are studied by V. Karakovsky, A. Kiryakov, I. Kotov, E. Shiyanov, E. Yamburg and others. From the perspective of synergetics, the problem of education is researched in the writings of $\mathrm{O}$. Astafiev, L. Bevzenka, V. Budanov, I. Dobronravova, V. Ilyin, N. Kochubei, V. Lutay, V. Skotnogo.

Theoretical and methodological analysis of the creative nature of pedagogical activity is presented in the papers of D. Wilkeev, M. Kashapova, T. Kiselyova, O. Korneeva, Yu. Kornilov, V. Slastoninna and others. Content, structure and signs of pedagogical creativity are presented in the explorations of A. Antonov, O. Dunaev, V. Kan-Kalyk, L. Petryshyn, and other researchers. Due to the research of national and foreign scientists are defined the fundamental characteristics, principles, methodological approaches in the formation of educational systems and paradigms.

The purpose of the paper. The systematic analysis of the methodological and practical aspects of the creative model of education, the mechanisms, and the strategy for its formation, remains without a proper comprehensive study. Therefore, the purpose of the article - is to identify the conceptual displays of the creative activity of the individual in a culture and to establish its significance in the formation of educational models.

Statement of basic materials. Education is a model of culture, an autonomous, local sphere, in which the core socio-cultural processes are concentrated and produced. J. Baudrillard defines that this artificial environment presents "the coherency of the cultural system of signs» [1, p. 46]. This system of interconnections forms a general model of relations between man and the world and determines the nature of the human creative activity in its broad sense. Accordingly, educational models with their own autonomous functioning and selfdevelopment logic, which is determined by a system of views, the type of socio-cultural relations, ideological processes and factors of innovative development are created.

Each educational system determines its own ideal - the model of human activity, which concentrates basic valuable reasons of the existence and the ways of their implementation. In the basis of this activity is the creative potential of the individual, which is determined by axiological and ethical guidelines. The multidimensionality of the spiritual and moral nature of the creative potential of the individual is differently realized in social, cultural and economic practices from material or human capital to the phenomenon of wealth in general. This is due to the creativity of human activity, which makes it possible to construct images, to form models, to create systems of views. Creativity, thus, accumulates, broadcasts, updates social experience in the system of pragmatist technologies and life-conceptual reflections.

Therefore, the development of educational models can be considered as a dynamic process of actu- alization, emergence, establishment, crisis, change of components of human creative activity. So it is reasonable to trace the formation and development of educational models not from the point of view of identifying their own pedagogical phenomena, but marking the display of the creative activity of the individual as a socio-cultural entity. Thus, the study of the dynamics of educational systems through the identification of their creative activity of the individual enables the development of a creative model of education. This involves the defining of idealizations that characterize the types of relationships between man and the world and the display of their creative activity. This is about contemplative, operational, innovative and co-evolutionary types of relationships in the "man-world» system.

Contemplative type of activity characterizes the essence of traditional culture, in which a person adapts to the fundamental characteristics of the universe, which are basic for all human activity. Ancient philosophers understood the essence of tradition as an ideal that has deep cosmic meaning in human activity. The laws of the universe are absolute and immutable, and even in the process of transformation of the world, the creation of a new, man interprets his activity and thinking on behalf of the "very» world, and recognizes himself as its function, acting "on behalf» of the universe. According to this model, a person does not oppose the world and does not state his own exclusive subjectivity. The universe is absolute, and human creativity is-relative, a carrier of the essential features and tendencies of the universe.

Ancient upbringing - paideia - focused on achieving harmony of mind, will and desires. The principle of similarity of the microcosm to the macrocosm has become fundamental to the formation of a free active citizen of the polis. According to Socrates, if you want to change the world - first change it for yourself. In the works "State» and «Laws» Plato interprets the teaching of philosophers and warriors (the elite of the ideal state) as a fundamental basis for the prosperity of society as a whole. Accordingly, the basis of rationalistic ethics was education as a self-improvement of man - an assimilation to cosmic harmony [1]. In the days of antiquity, the traditional model of education - contemplative was formed, the purpose of which was to educate an active person, who was to lead a correct, balanced life in an ideal state, which was the key to his spiritual well-being. Paideia is the transfer of knowledge and skills that are necessary not only for life, but above all for the formation of the character, the individual's spiritual qualities, that's why, it included physical training, music, verse, singing, rhetoric, ethics, and the like.

The idea of Paideia was inherited by Christian education (scholasticism), but the original meaning was transformed, since it was inserted into the context of the religion of salvation. As the ideal of the citizen of the policy disappeared and education began to relate the person with the truths of the Christian religion. But as the basic principle remains the purposeful formation of a person in accordance with certain ideals, determined by the dominant outlook. Accordingly, the goal of education is the harmonious formation of man through spiritual development. In the contemplative model of education, a person is 
assigned with the role of a "clean board", on which nature leaves an autograph, the object is an active side, the subject is passive. In education, the student is an "empty vessel», which the teacher fills with knowledge. Contemplative model is static, antinomy - if the world changes, then it is not changed by human. The world is transformed independently and a person with his own creativity is woven into this precisely process.

The Renaissance creates the foundation for the development of a secular model of education, the purpose of which is the systematization of knowledge - the metaphysics of things changes to metaphysics of knowledge. A new ideal of education is formed - oriented not so much on the perception of God and salvation of the soul, but on the realization of abilities and opportunities of man, the development of sciences for the studying and transformation of nature. The religious component is gradually shifted to the background, as society's outlook is changing - education gradually emanates from the church monopoly. Takes place the recognition of the priority of the active - living attitude of man to the universe. The human is no longer satisfied with the universe and he tries to change it with his own creative efforts. Culture becomes an instrument of transformative human activity in the interests of meeting the ever-increasing needs of society. With the development of science and the transformation of the world into a paradigm, "man emancipates himself from medieval scarcity and frees himself for himself». It is in this that M. Heidegger sees the essence of the New Time era: «As the result of the liberation of man, the New Times brought subjectivism and individualism» [2, p. 48]. Human becomes a subject, a reference point with which changes the perception of the entity as a whole. Science becomes an irreplaceable form of this self-affirmation in the world and the only perspective for knowledge of the nature of things.

The essential feature of the operational type of creativity becomes technology, which, according to V. Rosin, is «a peculiar counterpart of religion» [5, p. 56]. This peculiar adjustment of religion and technology has caused a socio-economic shift - a rapid economic development, embracing the transformation of the universe, basing on the achievements of science and technology. Nature and society became dependent on the creativity of the person who received the status of the almighty subject.

The purpose of education is a rationalist, a useful member of society, ready to follow certain moral norms. Horizons of man and education are determined by society, which gradually becomes a single social reality. If in the ancient education the social horizon of man was a polis and the goal of education - an ideal citizen of the polis, then in the New time, a citizen changes to subject of the state. The universalism of the contemplative model of education remains in the past. An operational model of education is formed, the purpose of which is to educate a citizen of a certain state and the bearer of a certain national culture. Operational creativity becomes synonymous to "true reality" and receives another temple - the University. B. Ridings describes this model, which became a peculiar result of the discussions about education, in which took part I. Kant, F. Schiller, I. Fichte: «The plan of the Berlin
University, created by Humboldt, envisaged a fundamental reorganization of the discourse of knowledge, as a result, the university had to take over the cultural function entrusted to him by the state: the search for the objective cultural meaning of the state as a historical greatness and, at the same time, the subjective moral upbringing of the citizens-subjects as potential carriers of this identity» [4, p. 89].

The formation of an industrial society, cultural and structural crisis influenced the establishment of social functions in education - the training of skilled personnel for a technologized economy, the development of science and educated citizens, able to participate in the electoral process. The idea of education as a spiritual approach to God and assimilation to it became anachronism. The worldview and social context of education have changed either. For O. Comte, J. Mill, G. Spencer education is, first of all, the mechanism of human adjustment to society, the development of skills necessary for vigorous activity in the social and professional environment. The role of education is realized as a tool for ensuring social mobility. That is, education is becoming more and more utilitarian, and the idea of education as the instrument of formation of a harmonious personality is eliminated. Operating model of education - «knowledge for the sake of domination" (M. Scheler). Man conquers nature, expands his capabilities, rationally manages the society, develops production and technology, which provides unprecedented value and demand for knowledge and education. So education loses its anthropological dimension, that is, the content of anthropological is reduced to social-functional.

With the acceleration of technological development processes, the focus on innovation, the expansion of technical capabilities of the individual in the information society, the purpose of education becomes the production of competent people who are able to continuously actualize their own creativity in order to increase their competitiveness. Thus, there is a certain gap between human activity and reality. Operational, classical education has tried to overcome this gap by creating a universal model of the correspondence of the human's inner world to social requirements. The operational model of education has thus become a powerful mechanism for the artificial modeling of human behavior. As a result, the attitude of man to the world was built up within the framework of forming and socialized approaches in classical pedagogy. Formatting technology of education allowed to manage human behavior: to encourage socially positive actions and to limit socially negative ones. These approaches characterize the linear principle, that is firmly built in the pedagogical consciousness, for development of human in the frames of its social effectiveness. But in order to be successful in today's heterogeneous world, which constantly puts forward new, unexpected demands, one cannot rely solely on traditional patterns of planning and behavioral patterns. An innovative model of education that focuses on rapid success, does not manage to respond to changes and needs of man and society.

For the new challenges of the information society, innovation education responds by its divergence. The gap between "man and reality» it overcomes by "polyteorethics», "multiparadigma», trying to 
preserve the plurality of approaches instead of creating conceptual foundations for their synthesis. Today, education is not aimed at forming a holistic scientific outlook. At its best, education provides scientific fragments of the world, which are almost unrelated to each other and do not satisfy all human needs. It thus creates a dynamic scheme of all possible responses, reactions to certain basic problem situations. Such system expands the boundaries of freedom and determines them at the same time. So it opens up a series of creative possibilities that are possible only as a response to a particular situation that the system articulates itself. In such way, it sets the limits of possible practical actions. By trying to preserve the plurality of answers, modern education has turned into a set of divergent educational practices that lack common hermeneutical foundation [3].

Today, the excessive human creativity, which is absolutized by the innovative approach, has become a threat to the existence of life on Earth, which accelerates the global eco-cultural crisis. This testifies that the operational and innovative types of personality's activity have exhausted themselves. Further socio-cultural development is possible in the conditions of co-evolutionary creativity, which involves the parity of man and the universe, orients the creative activity of the individual to protect coexistence in the world, because by taking care of nature, a person takes care of himself and vice versa.

The creative model of education is a necessary synthesis of contemplative, operational and innovative educational models, the feature of which is the principle of self-determination of educational activity. At the stage of formation, it must reflect the fundamental features of the information society and the co-evolutionary relations of the "manworld» system, in particular:

1) The accelerated pace of social dynamics requires education to ensure the readiness of the individual to unpredictable changes in the information universe.

2) The formation of autonomous-humanistic type of consciousness of the individual requires education to ensure its opportunities for self-organization as a key factor in social activity, the need for self-development and self-education throughout the life, the formation of open, partner relationships and cooperation.

3) Digital information technologies, electronic media as a priority form of communication require the creation of a creative informational educational environment, where the development of cyberspace will not be the goal of education, but the mechanism of self-development of the individual.

4) Civil society as a priority form of social organization requires the participation of its institutions in the functioning of the education system not only at the level of choice of the proposed educational services, but above all at the level of the customer of education and the public controller of all stages of the educational process. The creative model presupposes an open and public nature of education, where the customer is a civil society, and the state - is mainly an organizer and guarantor of the quality and availability of education.

5) Polyculture communicative nature of modern culture, requires from the educational system providing of social mobility, tolerance and the development of intercultural competence.

6) Multivariation of information culture requires from the education the introduction and scientific and methodological support of individual educational trajectories.

7) The convergent nature of modern culture requires the introduction and provision of principles of openness and transference in education, which involves the active interaction of subjects of the educational process with representatives of other industries on the basis of cooperation of opportunities and resources.

Conclusions. The research of socio-cultural development and the types of creative activity of the person defined in the educational models, allows to fix, on the one hand, the isomorphism of education - the representation in the educational models of the signs of individual's activity, and on the other hand - to define education as a mechanism of cultural cultivation as within its boundaries a cultural entity is formed, which is capable of implementing the socio-cultural programs of the future. At the stage of formation, the creative model of education should reflect the fundamental features of the information society and co-evolutionary relations. In the case of the discrepancy of these signs, in education, as in a subsystem of culture, starts a crisis of transition period. There are two possible ways out from this situation: either the subsystem adapts to the classification features of a new culture, and then there is further cultural evolution, or the subsystem returns to traditional forms, which leads to cultural stagnation.

\section{References:}

1. Bodrijjar Zh. (2007). Sistema veshhej [The System of Objects]. M. : Direkt-Media, 224 p. (in Russian)

2. Hajdegger M. (1997). Bytie i vremja [Being and time]. M. : Ad Marginem, 457 p. (in Russian)

3. Illjahova M. (2014). Modus andragogiki u sinergetichnij modeli osviti. Sinergetika i osvita : Monografija / Za red. akad. V.G. Kremenja. [The modus of andragogy in the model of synergistic education]. K. : In-t obdarov. ditini NAPN Ukrayni, pp. 114-137. (in Ukrainian)

4. Ridings B. (2008). Universitet v ruinah / Per. s angl. A.M. Korbuta; Otv. red. M.A. Gusakovskij [The university in ruins]. Minsk : BGU. 248 p. (in Russian)

5. Rozin V. (2006). Myshlenie i tvorchestvo [The torment and creativity]. M., pp. 45-67. (in Russian) 